\title{
A 44 Year Old Man with Chronic Myeloid Leukemia and Mass at Right Lower Leg
}

\author{
Laki-laki 44 Tahun dengan Chronic Myeloid Leucemia dan Massa Tungkai Kanan Bawah
}

\author{
Ahadini Islamiah, Shinta Oktya W \\ Laboratorium IImu Penyakit Dalam Rumah Sakit Umum Daerah Dr. Saiful Anwar Malang
}

\begin{abstract}
Chronic myeloid leukemia (CML) is a clonal myeloproliferative disorder of primitive hematopoetic stem cells that is characterized by overproduction of myeloid series cells, splenomegaly, and leukocytosis. We reported a case of 44 years old male with CML who complained about swelling right leg and pain for 3 month. It had been diagnosed as CML for 3 years, and he took hydroxyurea but stopped for a year due to economic problem. The results of clinical examination, laboratory, biopsy, and radiology showed a result matched to CML with soft tissue mass. The results of Fine Needle Aspiration Biopsy (FNAB) of fragmented histiocytes leg mass, multinucleated giant cells, and atypical nucleated with a possibility of fibroma with atypical nucleated cells. Magnetic resonance imaging (MRI) showed multilocular lobulated soft tissue mass from the popliteal region to the cruris dextra, cyst mass high protein dd/solid tumor with vascular encasement and lesions in bone marrow replacement, and fluid collection on bursa parapatella. The patient was treated with hydroxyurea and showed clinical improvement and decreased mass size in the legs.
\end{abstract}

Keywords: Chronic myeloid leukemia, CML, hydroxyurea, mass leg

\section{ABSTRAK}

Chronic myeloid leukemia (CML) merupakan gangguan mieloproliferatif klonal dari sel stem hematopoetik primitif ditandai dengan overproduksi sel seri myeloid, splenomegali dan leukositosis. Kami laporkan kasus CML laki-laki, 44 tahun, dengan keluhan kaki kanan bengkak dan nyeri 3 bulan, didiagnosa CML 3 tahun, menggunakan hydroxyurea, namun berhenti sejak setahun karena masalah ekonomi. Hasil pemeriksaan klinis, laboratorium, biopsi dan radiologi menunjukkan hasil sesuai CML dengan soft tissue mass, dengan hasil Fine Needle Aspiration Biopsy (FNAB) massa tungkai fragmen histiosit, multinucleated giant cells dan atypical nucleated, mungkin suatu fibroma dengan atypical nucleated cells. Magnetic Resonance Imaging (MRI) menunjukkan soft tissue mass multilocular lobulated pada region poplitea hingga cruris dextra, cyst mass high protein dd/ solid tumor dengan vascular encasement dan lesion pada bone marrow replacement, dan fluid collection pada bursa parapatella. Pasien diterapi dengan hydroxyurea dan menunjukkan perbaikan klinis dan penurunan ukuran massa di kaki.

Kata Kunci: Chronic myeloid leukemia, hydroxyurea, leg mass

Korespondensi: Ahadini Islamiah. Laboratorium IImu Penyakit Dalam Rumah Sakit Umum Daerah Dr. Saiful Anwar Malang, Jl. Jaksa Agung Suprapto No. 2 Malang Tel. (0341) 366242 Email: adhesengadji80@gmail.com

DOI: http://dx.doi.org/10.21776/ub.jkb.2017.029.04.17 


\section{INTRODUCTION}

Chronic myelogenous leukemia (CML), also called as chronic myeloid leukemia, chronic myelocytic leukemia, and chronic granulocytic leukemia, is a clonal myeloproliferative disorder of the primitive hematopoietic stem cell. It is characterized by overproduction of cells of the myeloid series, which results in marked splenomegaly and leukocytosis. Chronic phase chronic myeloid leukemia (CML-CP) can last for years and continues through an accelerated phase en route to a blast crisis resembling acute myeloid leukemia or lymphoid leukemia. Basophilia and thrombocytosis are common. A cytogenetic characteristic abnormality, the Philadelphia ( $\mathrm{Ph}$ ) chromosome, is present in the bone marrow cells in more than $90 \%$ of cases. Most patients ( 85 to $90 \%$ ) present in the chronic phase. Eventually, if poorly controlled, Chronic Myeloid Leukemia (CML) evolves into the accelerated and blastic phases. Chronic Myeloid Leukemia $(\mathrm{CML})$ is a type of cancer that starts in the bloodforming cells of the bone marrow and invades the blood. In CML, leukemia cells tend to build up in the body over time, but in many cases people don't have any symptoms for at least a few years. In time, the cells can also invade other parts of the body, including the spleen. Chronic Myeloid Leukemia (CML) can also change into a fastgrowing acute leukemia that invades almost any organ in the body. Most cases of CML occur in adults, but very rarely occurs in children. In general, the treatment in children is the same as for adults (1-4).

The American Cancer Society's estimates for chronic myeloid leukemia (CML) in the United States in 2013 were about 5,920 new cases that would be diagnosed as CML $(3,420$ in men and 2,500 in women), and about 610 people would die of CML (40 men and 270 women). Chronic Myeloid Leukemia (CML) accounts for a little over $10 \%$ of all new cases of leukemia. The average person's lifetime risk of getting CML is about 1 in 625. This disease is slightly more common in men than in women. It is also more common in whites than in African-Americans. The average age at diagnosis of CML is around 65 years. Over half of cases are diagnosed among people in 65 and older. This type of leukemia mainly affects adults, and is only rarely seen in children. Dramatic progress has been made in treatment over the past several years, so most people with $\mathrm{CML}$ are now surviving at least 5 years after diagnosis. Because the highly effective drugs are still fairly new, the average survival of people now being diagnosed with $C M L$ is not known $(1,2,5)$.

Symptoms of CML could include weakness, fatigue, night sweats, weight loss, fever, bone pain, an enlarged spleen (felt as a mass under the left side of the ribcage), pain or a sense of "fullness" in the belly, feeling full after eating even a small amount of food, but these aren't just symptoms of CML. They can occur with other cancers, as well as many non-cancerous conditions. Some patients have bone pain or joint pain caused by leukemia cells spreading from the marrow cavity to the surface of the bone or into the joint $(2,5,7)$.

The risk of getting CML increases with age. This disease is slightly more common in males than females, but it is not known why. There are no other proven risk factors for $\mathrm{CML}$. The risk of getting CML does not seem to be affected by smoking, diet, exposure to chemicals, or infections. Besides, CML does not run in families. Sometimes people inherit DNA mutations from a parent that greatly increase their risk of getting certain types of cancer, but inherited mutations do not cause CML. Deoxyribonucleid acid (DNA) changes related to $\mathrm{CML}$ that occurs during the person's lifetime, rather than having been inherited before birth. Multiple primary cancer is a specific malignant tumor type, manifesting as more than one primary tumor diagnosed in the same patient, either simultaneously or sequentially. The major hematological conditions in patients with multiple malignancies include multiple myeloma, myelodisplastic syndrome, non-Hodgkin's lymphoma, and chronic myelogenous leukemia. A case of CML with a solid tumor present is a rare case. $(1,5,6)$.

\section{CASE}

A 44-year old married man with two children came to hospital with general weakness for 2 months and swollen leg for 3 months before admission. The patient said that his right leg was bigger than the left side, and he felt pain while walking that made him used walking aid. He also complained his stomach was bigger in the last one year, and sometimes he felt nausea without vomiting. Previously, he was admitted twice in private hospital, and had been diagnosed as CML (chronic myelocytic leukemia) and took hydroxyurea routinely, but already stopped a year ago because of financial problem. He complained losing body weight for about $20 \mathrm{~kg}$ with a history of swollen leg in 2010 and 2011. The patient was a worker in chemical division of shoe manufacturing company for 22 years and has retired because of his illness.

Physical examination revealed $120 / 70 \mathrm{mmHg}$ blood pressure, $88 \mathrm{bpm}$ pulse rate, $18 \mathrm{tpm}$ respiratory rate, 36.7 $\mathrm{C}$ axillary temperature we found anemic conjunctiva, splenomegaly (schuffner VI-VII), right and left leg edema, mass $(8 \times 7 \times 7 \mathrm{~cm})$ at right leg, $51 \mathrm{~cm}$ leg circumference, lymphadenopathy of right inguinal. The other findings were within normal limit.

Laboratory result showed $5.0 \mathrm{~g} / \mathrm{dl}$ hemoglobin level, $422,920 / \mu \mathrm{L}$ leukocyte count, $13.9 \%$ hematocrite, $518,000 / \mu \mathrm{L}$ thrombocyte count. Differential count showed 2\% eosinophyl, 3\% basophyl, 45\% netrophyl, 0\% limphocyte, $0 \%$ monocyte, $9 \%$ stab, $5 \%$ promyelocyte, $35 \%$ myelocyte, and $1 / 100$ normoblast. Blood smear showed anemia normochrom anisocytosis and increased impression of leucocyte and platelet count with giant thrombocyte $(+)$. Laboratory finding also revealed 3.38 $\mathrm{g} / \mathrm{dL}$ albumin, $8.8 \mathrm{mg} / \mathrm{dL}$ uric acid, $55.1 \mathrm{mg} / \mathrm{dL}$ ureum, and $1.31 \mathrm{mg} / \mathrm{dL}$ creatinin, with prolonged of hemostatic function. Serum electrolyte, liver function test, bilirubin and urinalysis were within normal range. Abdomen ultrasonography (USG) revealed splenomegaly. An electrocardiogram showed sinus rhythm with 80 beat per minutes heart rate. Chest X-ray revealed normal. Needle biopsy of lymphadenopathy inguinal showed acute lymphadenitis with some atypical cells which is CML figured. Doppler USG showed no appearance of deep vein thrombosis (DVT), and very large cyst mass on $1 / 3$ distal femur to $1 / 3$ distal tibia. Aspiration cytology showed lymphocyte cell and erythrocyte.

Needle biopsy of right leg mass showed fragmented histiocyte, multinucleated giant cells and cells with atypical nucleated, that might be fibroma with atypical nucleated cells. MRI finding showed soft tissue mass 
multilocular lobulated on poplitea region to cruris dextra, cyst mass high protein differential diagnose solid tumor with vascular encasement, lesion as bone marrow replacement, and fluid collection on parapatella burse.cardiogram showed sinus rhythm with heart rate 80 beat per minutes. Chest X-ray revealed normal. Needle biopsy of lymphadenopathy inguinal showed acute lymphadenitis with some atypical cells which is CML figured. Doppler USG showed no appearance of deep vein thrombosis (DVT), and very large cyst mass on $1 / 3$ distal femur to $1 / 3$ distal tibia. Aspiration cytology showed lymphocyte cell and erythrocyte. Needle biopsy of right leg mass showed histiocyte fragmented, multinucleated giant cells and cells with atypical nucleated, might be fibroma with atypical nucleated cells. Finding of MRI showed soft tissue mass multilocular lobulated on poplitea region to cruris dextra, cyst mass high protein differential diagnose solid tumor with vascular encasement, lesion as bone marrow replacement, and fluid collection on parapatella burse.

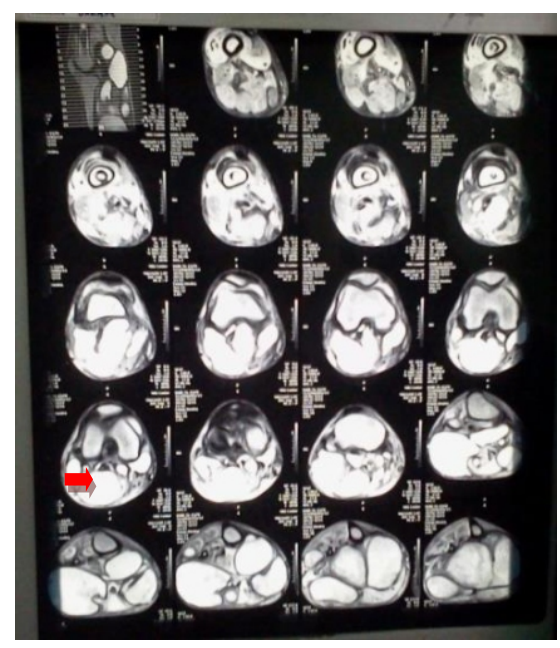

Figure 1. MRI finding

Note: arroe showed soft tissue mass multilocular lobulated on poplitea region to crurisdextra, cyst mass high protein dd/ solid tumor with vascular encasement, lesion as bone marrow replacement, and fluid collection on parapatella burse

\section{DISCUSSION}

The incidence of CML is 1.5 per 100,000 people per year, and the age-adjusted incidence is higher in men than in women (2.0 versus 1.2) (2). This incidence increases slowly with age until the middle forties, when it starts to rise rapidly. In this case, the patients was diagnosed as $\mathrm{CML}$ in his forties-age, and treated as CML used hydroxyurea. The diagnosis of $\mathrm{CML}$ is established by identifying a clonal expansion named of a hematopoietic stem cell possessing a reciprocal translocation between chromosomes 9 and 22. This translocation results in the head-to-tail fusion of the breakpoint cluster region (BCR) gene on chromosome 22q11 with the ABL (named after the abelson murine leukemia virus) gene located on chromosome 9 p34 $(5,8,9,10)$. Meanwhile, in this case, the patient was diagnose as CML based on clinical and laboratory finding The case of CML with mass is a rare case, which is may occur in $3 \%$ of CML patients, and have not been found before in Saiful anwar Hospital Malang.
No clear correlation with exposure to cytotoxic drugs has been found, and no evidence suggests a viral etiology. In the pre-imatinib era, cigarette smoking accelerated the progression to blast crisis and therefore adversely affected survival in CML. Atomic bomb survivors had an increased incidence; the development of a CML cell mass of $10,000 /$ ul took 6.3 years. No increase in CML incidence was found among the survivors of the Chernobyl accident, suggesting that only large doses of radiation can induce CML $(2,9)$. Similarly, the etiology of CML in our case is unknown, whether due to chemical agent because of working history as chemical worker in shoe factory, or other reason.

Lately, there has been a lot of discussion on the likelihood of development of a non-hematological second malignancy in patients with CML receiving chemotherapy or other immunosuppressive drugs $(5,9)$. One study about $\mathrm{CML}$ and adenocarcinoma colon showed a relationship, whereas 2 of the patients who had been treated with hydroxyurea had also been diagnosed as colon adenocarcinoma. Solid tumors may occur in $3 \%$ of patients with CML $(11,12)$. It has also been reported that mainly elderly patients with hematologic malignancies, including $\mathrm{CML}$ are likely to have multiple malignant neoplasms, mainly of the gastrointestinal tract. However, single cases of $\mathrm{CML}$ in patients treated for other malignancies have been reported, three were concerned as colon adenocarcinoma after treatment with chemotherapeutic agents (11). In this case a relationship between imatinib therapy or previous exposure to HU or cumulative effect of either exposures and development of colon adenocarcinoma cannot be completely excluded. However, an increased susceptibility of CML to secondary malignancies due to the malignant process of the disease itself cannot be ruled out. Only wider long term studies may clarify whether the concomitant occurrence of colon adenocarcinoma and CML is merely coincidental (3). In this case report, we suggested that mass in the leg was because of CML itself that was not treated well for a year, and become mass in the leg, supported by clinical history before and also improved condition of the patient and size of the mass after treatment of CML.

Another case of CML with solid tumor was reported in Shanghai, China, whereas the patient's WBC count decreased rapidly after just one week of hydroxyurea treatment, but the patient did not recover from the dyspnea symptoms. This raised the suspicion that another primary cancer was involved, which was revealed by VATS to be lung cancer. Because $\mathrm{CML}$ and lung cancer were found at the same time, hydroxyurea was chosen for its effectiveness in reducing WBC counts rapidly. Because the CML was controlled well and had little effect on long-term survival, the patient received six cycles of NP regimen and gefitinib maintenance therapy. During treatment for NSCLC, the patient did not receive any therapy for CML because routine blood tests were normal (7). Other case of $\mathrm{CML}$ and sarcoma granulocytic ever reported in medscape news that there was a 62 year old female patient with mass at right leg, biopsy result was sarcoma granulocytic, and BMP showed chronic myelogenous leukemia, and then patient was treated as CML. A case report of sarcoma granulocytic in oral cavity in patients with chronic myeloid leukemia was reported by Santos et al, and the patient was treated as CML also $(5,12)$.

Of all the leukemias, CML is among the least understood. 
While this disease can occur at any age, CML is extremely rare in children (about $2 \%$ of leukemia in children) and the average age of diagnosis is 40 to 50 years. Incidence rates are higher in males than in females, but unlike the other leukemia types, rates are higher in blacks than in whites in the U.S. High-dose radiation exposure may increase the risk of developing CML. Finally, CML has been associated with chromosome abnormalities such as the Philadelphia chromosome (9).

We treated the patients using hydroxyurea drugs after transfusion, started with high doses because of high increasing leucocytes. Chronic myelogenous leukemia is a clonal proliferative malignancy originating from a pluripotent HSC. Until recently, the therapeutic armamentarium for CML have been limited to allogeneic stem cell transplantation (SCT), conventional chemothetapywith agnets such as busulfan (BUS) and hydroxyurea (HU), and treatment with interferon (IFN)- $\alpha$ based regimens. All of these options have major drawbacks with respect to efficacy and tolerability. Currently, allogeneic SCT is the only treatment with known curative potential in CML. However, most patients are not eligible for this therapy because of advanced age or lack of

\section{REFERENCES}

1. American Cancer Society. Leukimia-Chronic Myeloid (Myelogenous). Atlanta: American Cancer Society; 2015; pp. 1-24.

2. Kantarjian H and O'Brien S. The Chronic LeukemiasChronic Myelogenous Leukimia. In: Goldman L and Schafer Al (Ed). Goldman's Cecil Medicine 24th edition. Philadelphia: Elsevier; 2012: pp. 1209-1214.

3. Kanellopoulou T, Kontopidou FN, Skondra M, Pliarchopoulau K, and Pectasides D. Chronic Myelogenous Leukemia and Colon Cancer: A Causal Relationship or Coincidence? Annals of Gastroenterology. 2011; 24(2): 140-141.

4. Vakili-Sadeghi $\mathrm{M}$ and Omranpour M. Chronic Myeloid Leukemia Following Colon Cancer Treatment: A Case Report and Literature Review. Caspian Journal Internal Medicine. 2013; 4(3): 739742.

5. Melo JV and Barnes DJ. Chronic Myeloid Leukaemia as a Model of Disease Evolution in Human Cancer. Nature Reviews Cancer. 2007; 7(6): 441-453.

6. Cui Y, Liu T, Zhou Y, et al. Five Cases Report of Solid Tumor Synchronously with Hematologic Malignancy. Cancer Research and Treatment. 2012; 44(1): 63-68.

7. da Silva-Santos PS, Silva BS, Coracin FL, Yamamoto FP, Pinto-Junior DD, Magalhães MG. Granulocytic a suitable stem-cell donor, and there is a significant risk of treatment-related morbidity and mortality. IFN- $\alpha$ treatment leads to both hematological and cytogenetic response in many chronic phase CML patients, and its effectiveness at treating a significant portion of $\mathrm{CML}$ patients suggests that IFN- $\alpha$ therapy may have some selectivity toward destroying $\mathrm{Ph}^{+}$leukemic cells or inhibiting the oncogenic activity of BCR-ABL. On the other hand, up to $20 \%$ of CML patients do not tolerate IFN- $\alpha$ therapy because of toxicity problems $(5,10)$.

Imatinib therapy has revolutionized the treatment of CML. In cases of newly diagnosed $\mathrm{CML}$, imatinib therapy is associated with an estimated 5-year survival rate greater than $90 \%$. If this favorable trend continues with longer follow-up, the median survival time in CML may exceed 20 years. During the first 5 years of follow-up, the annual mortality has been about $2 \%$. Many previously wellestablished poor prognostic factors in CML have lost much of their importance since the advent of imatinib therapy. With allogeneic stem cell transplantation, cures are expected in 40 to $80 \%$ of patients in chronic phase $\mathrm{CML}$, in 15 to $40 \%$ of those in accelerated phase $\mathrm{CML}$, and in 5 to $20 \%$ of those in blastic phase CML (2).

Sarcoma of the Oral Cavity in a Chronic Myeloid Leukemia Patient: An Unusual Presentation. Medicina Oral Patologia Oral y Cirugia Bucal. 2010; 15(2): e350-e352.

8. Horne SD, Stevens JB, Abdallah BY, et al. Why Imatinib Remains an Exception of Cancer Research. Journal of Cellular Physiology. 2013; 228(4): 665-670.

9. Jabbour E and Kantarjian H. Chronic Myeloid Leukemia: 2014 Update on Diagnosis, Monitoring, and Management. American Journal of Hematology. 2014; 89(5): 548-556.

10. Cohen M, Williams G, Johnson R, Duan J, Gobburu J, Rahman A, et al. Apprroval Summary for Imatinib Mesylate Capsules in the Treatment of Chronic Myelogenous Leukemia. Clinical Cancer Research. 2002; 8(5): 935-942.

11. Westin JR and Kurzrock R. It's About Time: Lessons for Solid Tumors from Chronic Myelogenous Leukemia Therapy. Molecular Cancer Therapeutics. 2012; 11(12): 2549-2555.

12. Jenkins $\mathrm{Cl}$ and Sorour Y. Case Report : A Large Extramedullary Granulocytic Sarcoma as the Initial Presenting Feature of Chronic Myeloid Leukemia. Medscape General Medicine. 2005; 7 (4): 23.

13. Druker B, Guilhot F, O'Brien S, et al. Five-Year Followup of Patients Receiving Imatinib for Chronic Myeloid Leukimia. The New England Journal medicine. 2006; 355(12): 2408-2417. 